\title{
EXCURSION TO PURLEY, KENLEY, AND WHYTELEAFE.
}

\author{
Saturday, July i4Th, I900.
}

Directors: The Presiden't and G. E. Dibley, F.G.S.

Excursion Secretary: W. P. D. Stebbing, F.G.S.

(Report by G. E. DIBLEY.)

The members arrived at Purley Oaks Station at 2.20 p.m., and proceeded to Haling Pit. The Director stated that the chalk is worked in the base of the Micraster cor-anguinum-zone, as described in the Proceendngs, vol. xvi, p. 490 , and referred to the absence of fossils characteristic of the upper part of the zone.

The large pits at Purley Junction were next visited, where the lithological character of the Chalk which marks the zone of Micraster cor-testudinarium in the London area was noted. Near Purley Station the President drew attention to some large, rounded masses of Woolwich and Reading conglomerate or "pudding stone," and stated that they are a prominent feature in the Caterham Valley; they extend as far as Croydon and could be traced in the various gravel-pits along the course of the Croydon Bourne, from the Kenley Waterworks to Purley Station.

At Kenley several fossils were procured from the Rose and Crown pit, including Terebratulina striata and a Nautilus in addition to the characteristic zone-fossils. Tea was very kindly provided by the Rev. T. Griffiths, M.A.. Votes of thanks, proposed by the President and Mr. E. T. Newton to Mr. and Mrs. Griffiths for their repeated acts of kindness to the Association, were accorded by acclamation.

After a vote of thanks to the Director had been duly acknowledged, a move was made to the Whyteleafe Lime Works, where the characteristic fossils of the zone of Terebratulina gracilis were obtained.

\section{REFERENCES.}

Geological Survey Map, Sheets 6 and 8.

Ordnance Survey Map, New Series, Sheets 270, 286.

1857. Godwin-Austen, R. A. C.- "On a Granite-Boulder in the White Chalk near Croydon." Quart. Fourn. Geol. Soc., vol. xiv., p. 253.

1870. Evans, C.-" On Some Sections of Chalk between Croydon and Oxted." Geol. Assoc. Separate publacation, price 6d.

1887. WOODWARD, H. B.- "Geology of England and Wales" (2nd Edition), pp. 403, 4 I 5 .

See also " Record of Excursions," pp. 80-82.

Proc. Geol, Assoc, Vol. XVI, Part io, November, 1900.] 